\title{
PERAN BEBERAPA ZAT GIZI MIKRO DALAM SISTEM IMUNITAS
}

\author{
Siswanto ${ }^{1}$, Budisetyawati², Fitrah Ernawati ${ }^{1}$ \\ ${ }^{1}$ Peneliti Pusat Teknologi Terapan Kesehatan dan Epidemiologi Klinik,Badan litbang Kesehatan \\ 2 Pusat Teknologi Intervensi Kesehatan Masyarakat,Badan litbang Kesehatan \\ siswantos@yahoo.com
}

\section{ABSTRAK}

Zat gizi mikro adalah vitamin dan mineral. Salah satu peran vitamin dan mineral adalah sebagai antioksidan yang mampu memperkuat sistem daya tahan tubuh manusia (sistem imun). Peran vitamin A banyak pada pemeliharaan sel epitel, dimana sel epitel merupakan salah satu jaringan tubuh yang terlibat di dalam fungsi imunitas non-spesifik. Vitamin $\mathrm{E}$ atau $\alpha$-tokoferol mempunyai peran penting di membran eritrosit dan lipoprotein plasma, vitamin ini mampu mempertahankan integritas membran sel karena vitamin $\mathrm{E}$ mempunyai cincin fenol yang mampu memberikan ion hidrogennya kepada radikal bebas. Demikian pula dengan vitamin $C$ sebagai donor elektron sehingga cepat memutus rantai reaksi SOR (Spesies Oksigen Reaktif) dan SNR (Spesies Nitrogen Reaktif). Selenium merupakan mineral kelumit yang penting untuk sintesis protein dan aktivitas enzim glutation peroksidase (GSH-PX). Selenium mempunyai peranan sebagai katalisator dalam pemecahan peroksida yang terbentuk di dalam tubuh menjadi ikatan yang tidak bersifat toksik. Maka karena itu kecukupan zat gizi terutama vitamin dan mineral sangat diperlukan dalam mempertahankan sistem kekebalan tubuh yang optimal sebagai upaya preventif agar selalu sehat.

Kata kunci: zat gizi mikro, antioksidan, sistem kekebalan tubuh

ABSTRACT

\section{THE ROLES OF MICRONUTRIENTS ON IMUNITY SYSTEM}

Micronutrients are vitamins and minerals. One of the roles of vitamins and minerals is as an antioxidant that can strengthen the human immune system. The role of vitamin $A$ is more in the maintenance of epithelial cells, which is one of the epithelial cells of the body tissues involved in the non-specific immune system. Vitamin E or a-tocopherol has an important role in erythrocyte membranes and plasma lipoproteins, they are able to maintain the integrity of the cell membrane because vitamin $E$ has a phenol ring capable of providing hydrogen ions to free radicals. Vitamin $\mathrm{C}$ as an electron donor that can break the chain reaction of Reactive Oxygen Species and Reactive Nitrogen Species. Selenium is a trace mineral that is essential for protein synthesis and enzyme activity of glutathione peroxidase (GSH - PX). Selenium has a role as a catalyst in the breakdown of peroxide produced by the body to become a bond that is not toxic. Therefore, the adequacy of nutrients, especially vitamins and minerals, are necessary in maintaining optimal immune system as a preventive health efforts.

Keywords: micronutrient, antioksidan, immune system

\section{PENDAHULUAN}

$\mathrm{D}$ efinisi zat gizi mikro adalah vitamin dan mineral. Walaupun vitamin diperlukan tubuh dalam jumlah kecil namun mempunyai peranan yang penting. Vitamin adalah zat esensial yang diperlukan untuk membantu kelancaran penyerapan zat gizi dan proses metabolisme tubuh. Begitu pula dengan mineral, dalam jumlah kecil beberapa mineral dibutuhkan tubuh untuk menjaga agar organ tubuh berfungsi secara normal. Beberapa mineral juga berfungsi sebagai ko-enzim dan antioksidan. Peran vitamin dan mineral sebagai antioksidan inilah yang membuat vitamin dan mineral mampu memperkuat sistem daya tahan tubuh manusia (sistem imun). ${ }^{1}$

Tulisan ini bertujuan untuk menganalisis peran beberapa zat gizi mikro terhadap sistem daya tahan tubuh melalui review pada beberapa buku teks dan hasil penelitian dalam dan luar negeri. Zat gizi mikro yang dimaksud 
adalah vitamin $A$, vitamin $E$, vitamin $C$, Selenium, Zinc dan Besi peranannya dalam sistem imun manusia.

\section{Sistem Imun}

Sistem imun (immune system) atau sistem kekebalan tubuh adalah kemampuan tubuh untuk melawan infeksi, meniadakan kerja toksin dan faktor virulen lainnya yang bersifat antigenik dan imunogenik. Antigen sendiri adalah suatu bahan atau senyawa yang dapat merangsang pembentukan antibodi. Antigen dapat berupa protein, lemak, polisakarida, asam nukleat, lipopolisakarida, lipoprotein dan lain-lain. Sementara itu antigenik adalah sifat suatu senyawa yang mampu merangsang pembentukan antibodi spesifik terhadap senyawa tersebut. Berbicara daya tahan tubuh, kita sering mendengar imunogen yaitu senyawa yang dapat merangsang pembentukan kekebalan/imunitas, dan imunogenik adalah sifat senyawa yang dapat merangsang pembentukan antibodi spesifik yang bersifat protektif dan peningkatan kekebalan seluler. Jika sistem kekebalan melemah, kemampuan untuk melindungi tubuh juga berkurang, sehingga patogen, termasuk virus dapat tumbuh dan berkembang dalam tubuh. Sedangkan reaksi yang dikoordinasi selsel, molekul-molekul terhadap mikroba dan bahan lainnya disebut respon imun. ${ }^{2}$

Respon imun terhadap benda asing secara garis besar dibagi dalam dua sistem utama, yaitu innate / non spesifik/bawaan dan adaptif/acquired atau imunitas spesifik. Imunitas adaptif akan bekerja apabila imunitas bawaan (innate) tidak dapat meniadakan infeksi dalam waktu dekat/pendek. Selanjutnya, pada saat serangan kedua benda asing ke dalam tubuh, sel $\mathrm{B}$ dan $\mathrm{T}$ memori akan membantu sistem imun beraksi lebih cepat. Imunitas bawaan (innate)/non spesifik terdiri dari garis pertahanan epitel, komponen seluler (makrofag, lekosit polimorfonuklear, natural killer (NK) dan dendritic cell (DCs)) dan komponen non-seluler dengan molekul marker/pendeteksi (CRP/C-reactive protein, serum amiloid protein, complement). Dalam bekerja, baik imunitas bawaan maupun imunitas adaptif tidak dapat dipisah-pisahkan, namun saling melengkapi. ${ }^{3}$

\section{METODE PENELITIAN}

Tulisan ini merupakan review dari berbagai kepustakaan dalam dan luar negeri dari mulai tahun 1984 sampai dengan 2007. Literature yang digunakan berupa artikel dalam jurnal dan buku teks yang dapat memberi wawasan yang lebih dalam pada tulisan ini dan tercatat sebanyak 40 buah.

\section{Zat Gizi Mikro}

Seperti telah disebutkan di depan bahwa zat gizi mikro meliputi vitamin dan mineral. Vitamin adalah komponen organik yang diperlukan dalam jumlah kecil, namun sangat penting untuk reaksi-reaksi metabolik di dalam sel, serta diperlukan untuk pertumbuhan normal dan pemeliharaan kesehatan. Beberapa vitamin berfungsi sebagai koenzim yang bertanggung jawab terhadap berlangsungnya reaksi-reaksi kimia yang esensial. Sebagian besar koenzim terdapat dalam bentuk apoenzim, yaitu vitamin yang terikat dengan protein. ${ }^{4}$

Mineral terutama mineral mikro terdapat dalam jumlah sangat kecil di dalam tubuh, namun mempunyai peranan penting untuk kehidupan, dan kesehatan. ${ }^{4,5}$ Salah satu peranan penting dari vitamin dan mineral tersebut yaitu dalam mempertahankan sistem kekebalan tubuh yang sehat.

Perlu diketahui bahwa sebagian besar vitamin dan seluruh mineral tidak dapat disintesa oleh tubuh sehingga harus diperoleh dari makanan terutama buah, sayur dan pangan hewani. Untuk memenuhi kebutuhan vitamin dan mineral ini maka diperlukan konsumsi makanan yang seimbang dan beragam. Dalam kenyataannya pada kondisi tertentu tidak semua vitamin dan mineral yang berasal dari makanan dapat dikonsumsi untuk memenuhi kebutuhan, maka pada kondisi seperti ini dapat dipenuhi dengan konsumsi suplementasi vitamin dan mineral. Kelompok dengan kondisi tersebut di atas disebut juga kelompok rawan meliputi kelompok lansia, anak-anak, kelompok individu dengan kondisi sosial ekonomi rendah, pengungsi, penduduk dalam kondisi darurat dan wanita usia subur (WUS) ${ }^{6}$ Kelompok lain yang memerlukan tambahan vitamin dan mineral adalah perokok ${ }^{7,8}$, orang yang terpapar stres oksidatif, terpapar polusi ${ }^{9,10}$, pengonsumsi alkohol 
berat ${ }^{11}$, terkena penyakit infeksi ${ }^{12}$, ibu hamil dan menyusui. ${ }^{13,14}$

Selain membantu proses metabolism zat gizi, vitamin dan mineral juga dapat sebagai antioksidan yang sangat mempengaruhi kualitas hidup manusia. Antioksidan adalah zat yang secara signifikan dapat menurunkan efek negatif akibat spesies yang reaktif seperti oksigen reaktif dan nitrogen reaktif yang terbentuk dalam tubuh. Beberapa vitamin dan mineral yang mempunyai peran sebagai antioksidan, diantaranya adalah vitamin A, vitamin $E$, vitamin $C$, selenium, zat besi dan zinc. 15

Berikut akan diuraikan peranan zat gizi tersebut di atas terhadap sistem imun.

\section{Peranan vitamin A dalam sistem imun}

Vitamin A mempunyai peranan penting di dalam pemeliharaan sel epitel. Sel epitel merupakan salah satu jaringan tubuh yang terlibat di dalam fungsi imunitas non-spesifik. Imunitas non-spesifik melibatkan pertahanan fisik seperti kulit, selaput lendir, silia saluran nafas. Peranan vitamin A dalam sistem imunitas non spesifik terlihat pada integritas mukosa epitel yang telah banyak diuraikan oleh Sommer dan Tarwotjo dan Karyadi et al. 16,17 Hasil penelitian mengungkapkan bahwa anak-anak kekurangan vitamin $A$ berisiko menderita penyakit saluran pernafasan dan mengalami keparahan penyakit diare. ${ }^{16,17}$ Vitamin A juga mempunyai peranan dalam selsel mukosa saluran cerna. ${ }^{18}$ Selain itu kekurangan vitamin A berdampak pada penglihatan yaitu dimulai dengan terganggunya integritas mukosa epitel, yang disebabkan karena hilangnya sel goblet penghasil mukus. ${ }^{19}$

Vitamin A selain mempunyai peranan penting pada imunitas non-spesifik, juga berperan pada imunitas seluler. Dalam bekerja imunitas seluler melibatkan sel darah putih baik mononuklear maupun polinuklear, serta sel NK (natural killer). Sel sel ini berperan sebagai sel yang menangkap antigen, mengolah dan selanjutnya mempresentasikan ke sel $\mathrm{T}$, yang dikenal sebagai sel penyaji atau APC (antigen presenting cell) dan selanjutnya memacu produksi sitokin dan pada akhirnya meningkatkan produksi sel B dan antibodi. Beberapa hasil penelitian menemukan bahwa peranan vitamin A pada imunitas seluler yaitu dengan cara mengurangi fungsi neutrofil, makrofag, dan sel NK'20,21

\section{Peranan vitamin $\mathrm{E}$ dalam sistem imun}

Vitamin $E$ atau a-tokoferol merupakan vitamin larut lemak. Vitamin ini banyak terdapat dalam membran eritrosit dan lipoprotein plasma. Tokoferol terutama a-tokoferol telah diketahui sebagai antioksidan yang mampu mempertahankan integritas membran sel. Peranan besar vitamin E sebagai antioksidan lebih disebabkan karena vitamin $\mathrm{E}$ mempunyai cincin fenol yang mampu memberikan ion hidrogennya kepada radikal bebas. ${ }^{1,3} \mathrm{Di}$ antara beberapa bentuk vitamin $\mathrm{E}$, bentuk a-tokoferol lebih efektif dibandingkan dengan beta, gama dan delta tokoferol. Ion hidrogen dari atokoferol sangat efektif dan cepat bereaksi dengan beberapa radikal bebas dan menghentikan radikal bebas sebelum merusak membran sel dan komponen-komponen sel lainnya. Proses vitamin E sebagai antioksidan dalam menghentikan reaksi berantai melalui beberapa proses, seperti proses inisiasi dan pengembangan. Proses inisiasi yaitu reaksi antara senyawa lemak seperti PUFA (poli unsaturated fatty acid) dengan radikal hidroksil kemudian menghasilkan radikal lipid (L). Jika radikal lipid sudah terbentuk maka akan bereaksi lagi dengan molekul oksigen dan terbentuk radikal peroksil Lipid (LOO). Reaksi ini dapat terus berlangsung atau seringkali disebut dengan reaksi berantai jika tidak dihentikan. Vitamin $E$ adalah salah satu antioksidan yang kuat untuk menghentikan reaksi berantai ini, karena vitamin E banyak terdapat di membran sel maka vitamin $\mathrm{E}$ mampu melindungi radikal bebas yang akan merusak membran sel yang banyak mengandung asam lemak tidak jenuh. Setelah vitamin $\mathrm{E}$ bereaksi dengan radikal bebas maka vitamin $E$ menjadi radikal vitamin $E$ atau vitamin $\mathrm{E}$ teroksidasi, dalam bentuk ini vitamin E memerlukan senyawa pereduksi seperti vitamin C dan NADPH (Nicotinamide Adenine Dinucleotide Phosphatase). Sifat vitamin E teroksidasi ini lebih stabil karena elektron yang tidak berpasangan pada atom oksigen mengalami delokalisasi ke dalam struktur cincin aromatik 22,23

Peranan vitamin $\mathrm{E}$ sebagai antioksidan yang melindungi membran sel secara langsung juga menjaga permeabilitas membran. 
Integritas membran sel ini sangat mempengaruhi fungsi imunitas terutama sel-sel imun utamanya sel $T$ helper dalam berinteraksi dengan antigen presenting cell (APC). Terjaganya integritas membran sel dapat menjaga/meningkatkan komunikasi sel yang pada akhirnya mempengaruhi produksi sitokin. Peran vitamin $\mathrm{E}$ dalam meningkatkan produksi sitokin telah banyak dilaporkan, diantaranya oleh Meydani et al. ${ }^{24}$ Selain itu peranan vitamin E pada sistem imun diantaranya dapat meningkatkan proliferasi sel T. ${ }^{25}$ Kekurangan vitamin $\mathrm{E}$ umumnya menyerang sistem syaraf, otot, pembuluh darah dan sistem reproduksi, defisiensi ini biasanya terjadi karena adanya gangguan absorbsi lemak dan gangguan transpor lipida. ${ }^{5,15}$

\section{Peranan vitamin $C$ dalam sistem imun}

Vitamin C dikenal sebagai antioksidan yang membantu menetralisir radikal bebas. Vitamin C sebagai antioksidan karena kemampuannya dalam mereduksi beberapa reaksi kimia, salah satunya vitamin $C$ mampu mereduksi spesies oksigen reaktif (SOR). Vitamin $C$ juga mempunyai peran sebagai donor elektron. Kemampuan vitamin $C$ sebagai donor elektron membuat vitamin $C$ menjadi sangat efektif sebagai antioksidan karena vitamin $C$ dapat dengan cepat memutus rantai reaksi SOR (Spesies Oksigen Reaktif) dan SNR (Spesies Nitrogen Reaktif). ${ }^{5}$

Peran vitamin $C$ di dalam sistem imun terkait erat dengan peran vitamin $C$ sebagai antioksidan. Oleh karena vitamin $C$ mudah mendonorkan elektronnya ke radikal bebas maka sel-sel termasuk sel imun terlindung dari kerusakan yang disebabkan oleh radikal bebas.

Winarsi 2007, melaporkan bahwa vitamin C meningkatkan fungsi imun dengan menstimulasi produksi interferon (protein yang melindungi sel dari serangan virus). Interferon adalah salah satu sitokin yang dihasilkan karena adanya komunikasi sel yang baik dan untuk menjaga komunikasi tersebut tetap baik maka diperlukan sel imun yang sehat dengan membran sel yang utuh. ${ }^{26}$

Vitamin C juga mempunyai peran dalam sintesa kolagen untuk menjaga kesehatan kulit. Kulit adalah salah satu jaringan tubuh yang berperan di dalam imunitas non spesifk. Kulit yang utuh dan sehat dapat menjaga masuknya unsur patogen ke dalam tubuh. Kulit merupakan barier pertama yang menjaga masuknya benda asing sehingga mencegah terjadinya infeksi.

Penelitian untuk menguji peranan vitamin C terhadap terjadinya infeksi telah dilakukan oleh Peter ${ }^{27}$, pada penelitian tersebut menunjukkan bahwa pemberian vitamin $\mathrm{C}$ dengan dosis $600 \mathrm{mg} /$ hari dapat menurunkan infeksi. Sementara itu hasil penelitian lain menyatakan bahwa bahwa konsumsi vitamin $\mathrm{C}$ 500-1000 mg/hari dapat memberikan efek antioksidan yang optimal.28

Kekurangan vitamin C dapat menimbulkan tanda-tanda klinis seperti perdarahan dan bengkak di gusi, rasa nyeri pada persendian akibat konsentrasi vitamin $\mathrm{C}$ di plasma darah dan leukosit yang sangat rendah. Kekurangan Vitamin $\mathrm{C}$ akut menyebabkan scorbut dan seseorang dengan kondisi kekurangan vitamin $\mathrm{C}$ dapat menurunkan kekebalan selulernya. ${ }^{29}$

\section{Peranan Selenium dalam sistem imun}

Selenium adalah mineral kelumit yang penting untuk sintesis protein dan aktivitas enzim glutation peroksidase (GSH-PX). Selenium dalam glutation peroksidase mempunyai peranan sebagai katalisator dalam pemecahan peroksida yang terbentuk di dalam tubuh menjadi ikatan yang tidak bersifat toksik. Peroksida dapat berubah menjadi radikal bebas yang dapat mengoksidasi asam lemak tidak jenuh yang ada pada membran sel, sehingga merusak membran sel. Oleh karena itu disebutkan dalam beberapa literatur bahwa selenium bekerjasama dengan vitamin $\mathrm{E}$ dan berperan sebagai antioksidan. Kerjasama tersebut terjadi karena vitamin $\mathrm{E}$ menjaga membran sel dari radikal bebas dengan melepas ion hidrogennya, sedangkan selenium berperan dalam memecah peroksida menjadi ikatan yang tidak reaktif sehingga tidak merusak asam lemak tidak jenuh yang banyak terdapat dalam membran, membantu mempertahankan integritas membran dan melindungi DNA dari kerusakan. 5,23

Integritas membran sel sangat diperlukan dalam sistem imunitas karena produksi sitokin sangat ditentukan oleh reseptor yang terdapat dalam membran sel, oleh karena itu selenium sangat diperlukan untuk meningkatkan imunitas seluler. Disamping itu kerusakan DNA 
juga akan mempengaruhi makrofag dalam fagositosis sehingga akan menurunkan fungsi makrofag sebagai APC.

Kekurangan selenium yang berdampak pada imunitas sudah banyak dilaporkan oleh beberapa peneliti. Hasil penelitian mengungkapkan bahwa pada keadaan kekurangan selenium akan terjadi penurunan titer IgG dan IgM, mengganggu kemotaksis neutrofil dan produksi antibodi oleh limfosit, mengganggu dan meningkatkan $\mathrm{CD} 4+$ dan menurunkan $\mathrm{CD} 8+.30,31$

\section{Peranan Zinc dalam sistem imun}

Zinc memegang peranan penting dalam banyak fungsi tubuh, sebagai bagian dari enzim atau sebagai kofaktor pada kegiatan lebih dari 300 enzim. Zinc juga berperan dalam proliferasi sel terutama sel mukosa. ${ }^{32}$ Zinc juga mempunyai peran yang penting dalam sintesa asam nukleat. Asam nukleat adalah senyawa yang esensial di dalam sel, sehingga keberadaan zinc mempunyai peranan penting di dalam fungsi imunitas seluler. Peran tersebut telah dibuktikan bahwa kekurangan zinc menurunkan aktivitas sel natural killer, $\mathrm{CD} 4+$ dan $\mathrm{CD} 8+$, juga menurunnya proliferasi limfosit. ${ }^{33,34}$ Peran zinc di dalam fungsi imunitas antara lain di dalam fungsi sel $T$ dan dalam pembentukan antibodi oleh sel $B$, serta pertahanan non spesifik.,35 Zinc juga diperlukan didalam aktivitas enzim SOD (superoksida dismutase) yang memiliki peran penting dalam sistem pertahanan tubuh, terutama terhadap aktivitas senyawa oksigen reaktif yang dapat menyebabkan stres oksidatif. ${ }^{26}$

Peran lain dari zinc adalah untuk sintesa protein. Protein merupakan komponen terbesar dalam pembentukan antibodi, maka dari itu keberadaan zinc sangat terkait dengan sistem imun humoral. Zinc juga mempunyai peranan pada produksi sitokin, hal ini terlihat adanya peningkatan produksi IL-2, setelah suplementasi zinc pada orang yang kekurangan zinc. ${ }^{34}$ Penurunan zinc juga terlihat mempengaruhi kemampuan sel NK untuk membunuh antigen. ${ }^{36}$ Sementara peneliti lain menunjukkan bahwa suplementasi zinc dapat mempercepat penyembuhan disentri pada lansia dan anak-anak, hal ini terkait dengan peranan zinc dalam proliferasi sel. ${ }^{37,38}$
Kekurangan zinc juga berimplikasi pada penurunan ketajaman indera perasa, melambatnya penyembuhan luka, gangguan pertumbuhan, menurunnya kematangan seksual, dan gangguan homeostasis.,539 Sedangkan pada anak-anak kekurangan zinc menyebabkan gangguan pertumbuhan dan pembentukan lgG.37,40

\section{Peranan besi dalam sistem imun}

Seperti kita ketahui bahwa besi sangat berperan dalam sintesa hemoglobin dan terkait erat dengan masalah anemia. Peranan zat besi berhubungan dengan kemampuannya dalam reaksi oksidasi dan reduksi, zat besi merupakan unsur yang sangat reaktif sehingga mampu berinteraksi dengan oksigen. Dalam keadaan teroksidasi, besi kehilangan tiga elektron sehingga memiliki tiga sisa muatan positif ( $\left.\mathrm{Fe}^{3+} / \mathrm{feri}\right)$, sedangkan dalam keadaan tereduksi besi kehilangan dua elektron sehingga memiliki dua sisa muatan positif $\left(\mathrm{Fe}^{2+}\right.$ (fero). Keberadaan besi dalam dua bentuk ion ini menyebabkan besi berperan dalam proses respirasi sel yaitu sebagai kofaktor bagi enzimenzim yang terlibat dalam reaksi oksidasireduksi. 5,35

Aktifitas SOD (superoksida dismutase) dan katalase bergantung pada zat besi ini. Antioksidan enzimatis bekerja dengan cara mencegah terbentuknya senyawa radikal bebas baru.22,26 Sebagian besar zat besi berada dalam hemoglobin, hemoglobin didalam darah membawa oksigen dari paruparu ke seluruh jaringan tubuh dan membawa kembali karbon dioksida dari seluruh sel keparu paru untuk dikeluarkan tubuh, selain itu zat besi juga berperan dalam imunitas dan pembentukan sel-sel limfosit. Disamping itu dua protein pengikat besi yaitu transferin dan laktoferin dapat mencegah terjadinya infeksi dengan cara memisahkan besi dari mikroorganisme, karena besi diperlukan oleh mikroorganisme untuk berkembang biak.

Kekurangan besi akan berdampak pada reaksi imunitas berupa aktivitas neutrofil yang menurun, dan sebagai konsekuensinya kemampuan untuk membunuh bakteri intraseluler secara nyata menjadi terganggu. Sel NK sensitif terhadap ketidakseimbangan besi dan memerlukan jumlah besi yang cukup untuk berdiferensiasi dan berproliferasi, jika 
tubuh kekurangan besi kemampuan sel NK untuk membunuh bakteri menjadi rendah. ${ }^{31,35}$

\section{SIMPULAN}

Kecukupan zat gizi terutama vitamin dan mineral sangat diperlukan dalam mempertahankan sistem kekebalan tubuh yang optimal. Karena sebagian besar vitamin dan seluruh mineral tidak dapat disintesa oleh tubuh, maka konsumsi makanan yang beragam dan seimbang sangat diperlukan utamanya sumber vitamin mineral seperti buah, sayuran dan pangan hewani.

Beberapa vitamin dan mineral mempunyai peran sebagai antioksidan yang sangat mempengaruhi kualitas hidup manusia diantaranya adalah vitamin $A$, vitamin $E$, vitamin $\mathrm{C}$, selenium, zat besi dan zinc. Zat gizi ini diperlukan dalam sistem pertahanan tubuh karena perannya sebagai zat gizi antioksidan.

\section{RUJUKAN}

1. Spears JW, William $P$ Weiss. Role of antioxidants and trace elements in health and immunity of transition dairy cows. The veterinary Journal 2008:176:70-76.

2. Baratawidjaja. Immunologi Dasar. Jakarta: Fakultas Kedokteran Universitas Indonesia. 2006.

3. Roitt Ivan M. Essential Immunology. Edisi 8. Widya Medika, Jakarta. 2003.

4. Piliang WG dan Al Haj SD. Fisiologi Nutrisi. Volume II Bogor: IPB Press, 2006

5. Almatsier S. Prinsip Dasar IImu Gizi. Jakarta:.Gramedia Pustaka Utama, 2006.

6. FAO/WHO. International Conference on Nutrition. World Declaration and Plan of Action for Nutrition. Roma: FAO, 1991

7. Polidori $\mathrm{CM}$, Patrizia $\mathrm{M}$, Willhem $\mathrm{S}$ and Sies H. Cigarette smoking cessation increases plasma levels of several antioxidant micronutrients and improve resistence towards oxidative challenge. British Journal of Nutr .2003; 90:147-150.

8. Pamuk ER, Byers T, Coates RJ, Vann JW, Sowel AL, Gunter EW et al Effect of smoking on serum nutrient concentration in African American women. Am J Clin Nutr 1994;59: 891-895.
9. Romieu I. Nutrition and lung health. Int J Tuberc Lung Dis 2005; 9:362-374.

10. Romieu I, Castro GF, Kunzli N, Sunyer J Air pollution, oxidative stress and dietary supplementations. A review. Eur Respir J 2008;31: 179-186.

11. Calder PC, Jackson AA. Under-nutrition, infection and immune function. Nutr Res Rev $2000 ; 13: 3-29$

12. Barringer TA, Kirk JK, Santaniello AC, Long Foley K, Michielutta R. Effect of a multivitamin and mineral supplement on infection and quality of life. Ann Intern Med 2003;138:365-371.

13. Lapido OA. Nutrition in pregnancy: mineral and vitamin supplements. Am J Clin Nutr 2000;72 (suppl):S280-S290.

14. Black RE. Micronutrients in pregnancy. British Journal of Nutrition 2001;85(Suppl.2):S193-S197.

15. Institute of Medicine (IOM). Dietary Reference Intakes for Vitamin C, Vitamin E, Selenium and Carotenoids. Washington DC.: National Academy Press, 2000

16. Sommer A, Katz J, Tarwotjo I: Increased risk of respiratory disease and diarrhea in children with preexisting mild vitamin $A$ deficiency. Am J Clin Nutr 1984; 40:10901095.

17. Karyadi E, West CE, Schultink W, Nelwan $\mathrm{ROHH}$, Gross R, Amin $\mathrm{Z}$ et al. A doubleblind, placebo controlled study of vitamin $A$ and zinc supplementation in persons with tuberculosis in Indonesia: effects on clinical response and nutritional status. Am J Clin Nutr 2002;75: 720-727.

18. Kotake-Nara E, Kushiro $M$, Zhang $H$, Sugawara $T$, Miyashita $K$ and Nagao A. Carotenoids affect proliferation of human prostate cancer cells. J Nutr 2000;131:3303-3306.

19. Long KZ, Montoya Y, Hertzmark E, Santos $\mathrm{JI}$, Rosado JL. A double-blind, randomized clinical trial on the effect of vitamin $A$ and zinc supplementations on diarrheal disease and respiratory tract infections in children in Mexico City. Mexico. Am J Clin Nutr 2006;83:693-700.

20. Stephensen CB. Vitamin A, infection, and immunity.Annu Rev Nutr 2001 ;21:167192. 
21. Villamor $E$, Fawzi WW.: Effects of vitamin A supplementation on immune responses and correlation with nutritional outcome. Clin Microbiol Rec 2005; 18:446-464.

22. Marks D, Marks A, Smith C. Biokimia Kedokteran Dasar. Jakarta: ECG. 2000.

23. Gropper SC, Smith JL, Groff JL. Advanced Nutrition and Human Metabolism. International Student Edition. Washington: Thomson Wadsworth, 2005.

24. Meydani SN, Han SN, Wu D. Vitamin E and immune response in the aged: molecular mechanism and clinical implication. Immunol Rev 2005; 205: 269284.

25. Lee Chun Yung, Fan Wan. Vitamin E supplemantation improves cell mediates immunity and oxydative stress of Asian men and women. J Nutr 2000:130:29322937.

26. Winarsi Hery. Antioxidan Alami dan Radikal bebas. Kanisius Jogjakarta. 2007.

27. Peters EM. Exercise immunology and upper respiratory tract infection. International Journal of Sport Medicine 1997:18:(Supl1)S68-S69.

28. Carol S and Arah K. Plasma saturated intakes of vitamin $\mathrm{C}$ confer maximal antioxidant protection to plasma. Journal of the American College of Nutrition 2001:20(6):623-627.

29. Chandra. Overview Micronutrient and immune function. 1997

30. Kiremidjian-Schumacher L, Roy M, Wishe HI, Cohen MW and Stotzky G. Suplementation with selenium augments the function of natural killer and lymphokine activated killer cells. Biological Trace Element Research 1996 :52: 227239.

31. Calder PC, Field C and Gill HS. Nutrition and Immune Function. London.UK. 2002.
32. Wintergerst Eva S, Silvia M, Dietrich $H$. Hornig. Contribution of selected vitamins and trace elements to immune function. Ann Nutr Metb 2007:51:301-323.

33. Prasad AS, Beck, Kaplan and Chandrasekar. Effects of zinc supplementation on incidence of infections and hospital admission in sickle cell disease (SCD). American Journal of Hematology.1998 : 61:194-202.

34. Prasad AS. Effect of zinc deficiency on immune functions. Journal of Trace Elements in Experimental Medicine 2000:13: $1-20$

35. FAOMHO. Human Vitamin and Mineral Requirement. Report of a joint FAO/WHO expert consultation. 2001. Bangkok. Thailand. Roma: Food and Nutrition Division.

36. Rink $L$ and Kirchner $H$. .. Zinc altered immune function and cytokine production . J Nutr :130:1407 S-1411S. 2000

37. Raqib R, Swapan KR, Jubayer M, Tasnim, Syeda. Effect of $\mathrm{Zn}$ supplementation on immune and inflammatory responses in pediatric patiens with shigellosis. Am J Clin Nutr $2004: 79(3): 444-450$.

38. Rahman MJ, Sarker P, Roy SK, Ahmad SM, Chisti J, Azim T, et al.. Effects of zinc supplementation as adjunct therapy on the systemic immune responses in shigellosis. Am J Clin Nutr 2005:81(2): 495-502.

39. Whittaker $P$. Iron and zinc interactions in humans. Am J Clin Nutr 1998:68:S442S446.

40. Dijkhuizen MA,Wieringa FT, West CE, Mucherdiyantiningsih, Muhilal Concurrement micronutrient deficiencies in lactating mothers and their infants in Indonesia. Am J Clin Nutr 2001:73:786791. 
